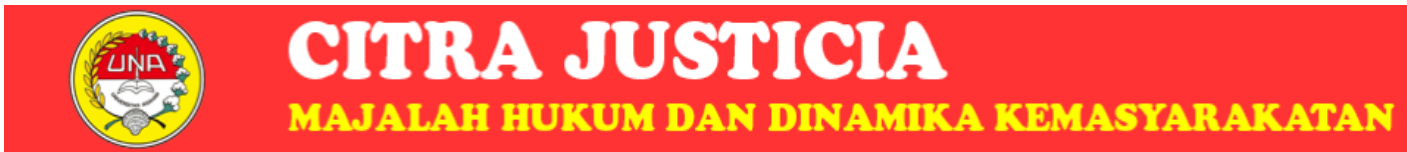

Volume 22 No. 1, FEBRUARI 2021 ISSN 2686-5750 (ONLINE)

ISSN 1411-0717 (CETAK)

\title{
KEBIJAKAN PERLINDUNGAN HUKUM PIDANA TERHADAP PEKERJA RUMAH TANGGA SEBAGAI KORBAN KEKERASAN OLEH MAJIKAN
}

\author{
Prisko Yanuarius Djawaria Pare ${ }^{1)}$, Andi Sofyan ${ }^{2)}$ Wiwie Heryani ${ }^{3)}$ \\ 1) Program Studi Pendidikan IPA, STKIP Citra Bakti \\ 2) Fakultas Hukum, Universitas Hasanuddin \\ ${ }^{3)}$ Fakultas Hukum, Universitas Hasanuddin \\ email: priskodjawaria@gmail.com ${ }^{1}$ andisofyan@gmail.com ${ }^{2)}$ wiwieheryani@yahoo.com ${ }^{3)}$
}

\begin{abstract}
ABSTRAK
Perlindungan hukum bagi pekerja rumah tangga merupakan bentuk penghormatan terhadap hak asasi manusia. Penelitian ni bertujuan mengetahui faktor-faktor penyebab kekerasan yang dilakukan oleh majikan terhadap pekerja rumah tangga; bentuk perlindungan hukum terhadap pekerja rumah tangga; da upaya-upaya penanggulangan kekerasan terhadap pekerja rumah tangga. Penelitian ini menggunakan metode studi lapangan (field research) dan metode kepustakaan (library research). Penelitian ini dilaksanakan di Kepolisian Resort Kota Besar Makassar, Pengadilan Negeri Makassar, Lembaga Bantuan Hukum Asosiasi Perempuan Indonesia Untuk Keadilan, (LBH APIK), Forum Pemerhati Masalah Perempuan Sulawesi Selatan, dan Pusat Pelayanan Terpadu Pemberdayaan Perempuan dan Anak Provinsi Sulawesi Selatan (P2TP2A). data yang diperoleh melalui dokumen mengenai kasus kekerasan yang menimpa pekerja rumah tangga di kota Makassar. Selain itu, dilakukan wawancara dengan pihak-pihak rekait seperti kepala unit perlindungan perempuan dan anak, Hakim Pengadilan Negeri Makassar, dan beberapa kordinator lembaga bantuan hukum. Hasil dari penelitian menunjukan bahwa faktor-faktor penyebab kekerasan terhadap pekerja rumah tangga yaitu: faktor interen yang mencakup keadaan jiwa atau kepribadian majikan yang otoriter, tidak mandiri, cepat emosi, dan keadaan rumah tangga yang tidak harmonis, serta kesalahan atau kelalaian yang dilakukan pekerja bak sengaja maupun tidak sengaja. Bentuk perlindungan hukum terhadap pekerja rumah tangga yaitu: perlindungan hukum preventif atau secara abstrak, dan perlindungan hukum represif atau secara konkret. Kemudian, upaya-upaya penanggulangannya yaitu: upaya pre-emtif (pencegahan), preventif dan represif (proses penindakan atau penegakan hukum bagi pelaku kejahatan berdasarkan bukti yang cukup).
\end{abstract}

Kata kunci: Perlindungan Hukum, pekerja rumah tangga, kekerasan dalam rumah tangga, korban. 


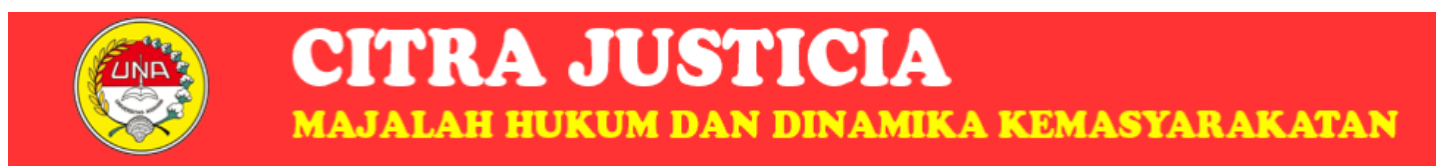

Volume 22 No. 1, FEBRUARI 2021 ISSN 2686-5750 (ONLINE)

ISSN 1411-0717 (CETAK)

\begin{abstract}
Legal protection for domestic workers is a form of respect for human rights.This research aimed to investigate the factors causing the violence commited by the employers on the household workers, the form of the legal protection on the household workres, and the efforts to cope with the violence againts the household workers. The research use the methods of the field research and the library research. The research was conducted in the police resort of macassar city, the first instance court of makassar, the legal aid intitution of the indonesian women association for justice (LBH APIK), women problem observer forum of south sulawesi, and the integrated servive center for the children and women empowerment of south sulawesi (P2TP2A). the data or document about the violence cases which fell on the household workers in makassar city were collected. Then, the researcher carried out inreviews with the related parties, such as the head of the women and the children protection unit, the judges of makassar fisrt instance court, and some cordinators of the legal aid institution. The research resulth indicated that the factors causing the violence workers were the internal factors, which included the condition of the personality of the authoritarian employers, the lack of autonomy, the quick emotion, and the condition of the inharmonius household, as well as the mistakes or carelessness behaviour of the workers, either intentionally. Then, the form of the legal protection on the workers werw the pereventive legal protection which was abstract an the repressive legal protection whicn was concrete, and the tackling efforts, such as the pre-emtif efforts (pre-emtif), preventif and repressive (the process of the execution or the law enforcement on whoever commited crimes based on the adequate proofs).
\end{abstract}

Keyword: Legal protection, household workers, violence in the household, victims.

\section{PENDAHULUAN}

Keutuhan dan kerukunan rumah tangga yang bahagia, aman, tenteram, dan damai merupakan dambaan setiap orang dalam kehidupan berumah tangga. Negara republik Indonesia adalah Negara berdasarkan Ketuhanan Yang Maha Esa dijamin oleh Pasal 29 UndangUndang Dasar Negara Republik Indonesia Tahun 1945. Keutuhan dan kerukunan rumah tangga dapat terganggu jika kualitas dan pengendalian diri tidak dapat dikontrol, yang pada akhirnya dapat terjadi kekerasan dalam lingkup rumah tangga (domestik) sehingga timbul ketidaknyamanan terhadap orang yang berada dalam rumah tangga tersebut, lebih khususnya bagi diri pekerja rumah tangga yang menjadi korban kekerasan oleh sang majikan ( Soeroso, 2011).

Kekerasan dalam rumah tangga bukanlah sesuatu yang asing yang kita dengar akhir-akhir ini. Pemberitaan mengenai kekerasan dalam rumah tangga selalu menjadi bahasan berita yang menarik ditanah air,terlebih kasus kekerasan yang menimpa pekerja rumah tangga yang disiksa oleh sang majikan, karena beberapa 


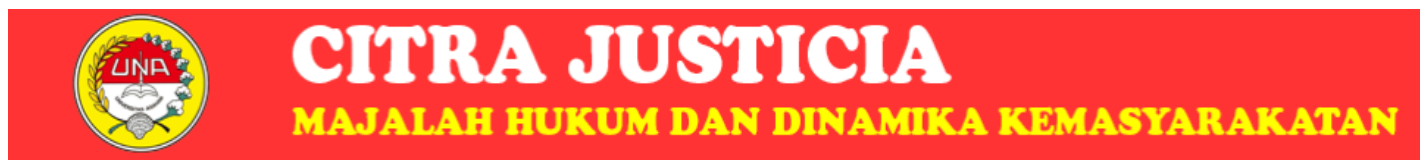

Volume 22 No. 1, FEBRUARI 2021 ISSN 2686-5750 (ONLINE)

ISSN 1411-0717 (CETAK)

faktor atau motivasi yang mempengaruhinya. Secara hukum yang dimaksud dengan kekerasan dalam rumah tangga adalah setiap perbuatan terhadap seseorang terutama perempuan, yang berakibat timbulnya kesengsaraan atau penderitaan fisik, seksual, psikis, dan/atau penelantaran rumah tangga termasuk ancaman untuk melakukan perbuatan, pemaksaan, atau perampasan kemerdekaan secara melawan hukum dalam lingkup rumah tangga (Khaleed, 2015).

Kekerasan terhadap pekerja rumah tangga merupakan salah satu bentuk perbuatan yang bertentangan dengan sendi-sendi kemanusiaan.itulah sebab-sebabnya perbuatan kekerasan terhadap pekerja merupakan salah satu perbuatan yang melanggar hak asasi manusia (HAM), sehingga dibutuhkan suatu instrumen hukum nasional tentang pengahapusan kekerasan dalam rumah tangga. Mengapa pekerja dikategorikan sebagai anggota keluarga rumah tangga bersangkutan, karena jika kita tinjau dari ketentuan Pasal 2 ayat (1) huruf c, maka pekerja masuk dalam lingkup rumah tangga, selama ia masih aktif bekerja di rumah sang majikan. Jika ia sudah keluar dan tidak bekerja lagi maka tidak terkategori lagi sebagai anggota keluarga rumah tangga yang bersangkutan. Oleh karena itu jika pekerja menjadi korban kekerasan oleh majikan, maka ketentuan hukum dalam undang-undang penghapusan kekerasan dalam rumah tangga yang berlaku bagi diri pekerja dalam mengakomodasi hak-hak yuridisnya, ketika ia menjadi korban (Dellyana, 1998).
Perlindungan hukum pidana terhadap korban kekerasan dalam rumah tangga, khususnya pekerja rumah tangga membutuhkan suatu pengkajian yang lebih mendalam tentang faktor penyebab terjadinya kekerasan dalam rumah tangga, upaya penanggulangan yang dilakukan oleh pemerintah, aparat penegak hukum, serta masyarakat, serta bagaimana bentuk implementasi dari perlindungan hukum yang diberikan kepada pekerja rumah tangga. Dalam peneliitian terdahulu menyebutan bahwa kasus penganiayaan terhadap pekerja rumah tangga yang di rilis oleh salah satu lembaga sosial jaringan advokasi pekerja rumah tangga (JALA PRT), bahwa penganiayaan terhadap pekerja rumah tangga pada hakikatnya adalah merupakan ketimpangan relasi sosial antara kekuasaan majikan dengan pekerja rumah tangga yang tidak setara yang sering disebut ketimpangan gender, yang secara sosial menempatkan posisi laki-laki lebih tinggi dari posisi kaum perempuan (Syukur, 2011).

Oleh karena itu upaya perjuangan yang dilakukan oleh berbagai lembaga sosial dan aparat penegak hukum dalam memberantas kasus kekerasan yang menimpa pekerja rumah tangga di kanca nasional maupun internasional terus dilakukan dengan berbagai upaya yang signifikan, termasuk mendesak kepada DPR-RI untuk segera membahas rancangan undang-undang perlindungan pekerja rumah tangga, serta menetapkan standar kontrak kerja yang baku terhadap perjanjian kerja antara majikan dengan pekerja rumah 


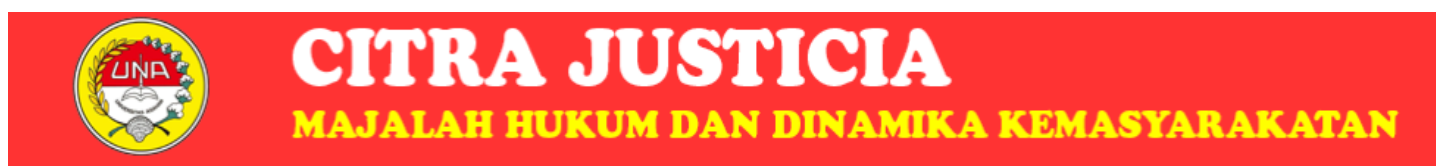

Volume 22 No. 1, FEBRUARI 2021 ISSN 2686-5750 (ONLINE)

ISSN 1411-0717 (CETAK)

tangga, agar jelas posisi hukum dan hak-hak yuridis dari pekerja di sektor domestik (Waluyo, 2012).

Untuk itu penelitian ini bertujuan untuk mengetahui atau mengkaji faktor penyebab kekerasan dalam rumah tangga, bentuk perlindungan hukum pidana bagi pekerja rumah tangga, dan untuk mengetahui upaya atau mekanisme penanggulangan terhadap kejahatan kekerasan dalam rumah tangga.

\section{METODE PENELITIAN Lokasi Penelitian}

Penelitian ini mengambil lokasi di kota Makassar dengan alasan bahwa kota Makassar memiliki masyarakat yang heterogen atau majemuk yang juga kegiatan masyarakat pun bervariasi,dan sering didengar terjadi kasus-kasus kekerasan terhadap pekerja rumah tangga. Lokasi penelitian ini meliputi Polrestabes Makassar, Pengadilan Negeri kelas 1A khusus Makassar, lembaga bantuan hukum APIK Makassar, forum pemerhati masalah perempuan Sulawesi selatan, internasional labour organization (ILO), cabang Sulsel, dan pusat pelayanan terpadu pemberdayaan perempuan dan anak provinsi Sulawesi selatan.(P2TP2A).

\section{Populasi dan sampel}

Populasi dalam penelitian ini adalah polrestabes Makassar, pengadilan negeri Makassar, lembaga bantuan hukum apik, forum pemerhati masalah perempuan, ILO sulsel, dan pusat pelayanan terpadu perempuan dan anak provinsi sulsel.jenis sampel yang digunakan dalam penelitian ini adalah purposive sampling, yaitu penentuan jumlah narasumber yang akan dimintai keterangan terkait permasalah yang diteliti. Dalam penelitian ini misalnya, Hakim (1 orang), panitera (2 orang), pihak Kepolisian, aparat PPA (2 orang), bagian hukum (1 orang). LBH APIK, ( 2 orang), FPMP (3 orang) ILO Sulsel (1 orang), dan P2TP2A (1 orang).

\section{Pengumpulan Data}

Dalam penelitian ini pengumpulan data yang digunakan adalah pengumpulan data primer, dan pengumpulan data sekunder, yang kesemuanya ini merupakan sumber atau bahan refrensi yang dijadikan dasar untuk mengkaji lebih dalam permasalahan yang diteliti. Pengumpulan data primer dilakukan dengan cara mengumpulkan data atau bahan hukum tentang kasus kekerasan dalam rumah tangga yang menyiksa pekerja rumah tangga pada lokasi penelitian seperti Polrestabes Makassar, Pengadilan Negeri Makassar, LBH APIK, FPMP Sulsel, P2TP2A provinsi Sulsel, dengan melakukan wawancara atau interview kepada pihak terkait seperti Hakim, Polisi, pekerja sosial dan kordinator ILO Sulsel, serta melakukan observasi atau pengamatan secara mendalam dan terperinci pada dokumen atau data mengenai kasus kekerasan terhadap pekerja di sektor domestik, dan melakukan studi kepustakaan pada perpustakaan fakultas hukum unhas dan perpustakaan pusat universitas hasanuddin. Kemudian pengumpulan data secara sekunder yaitu dengan melakukan penelusuran terhadap berbagai peraturan perundangundangan yang berkaitan dengan 


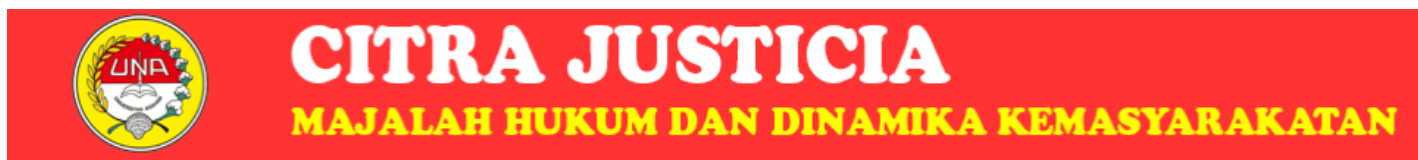

Volume 22 No. 1, FEBRUARI 2021 ISSN 2686-5750 (ONLINE)

ISSN 1411-0717 (CETAK)

masalah kekerasan dalam rumah tangga, yang mengakomodir kepentingan korban kejahatan, doktrin hukum, dan jurnal hukum.

\section{Analisis Data}

Dalam penelitian ini analisis data yang digunakan adalah dengan menggabungkan secara kseluruhan data primer dan data sekunder yang diperoleh pada lokasi penelitian dan berbagai literatur hukum, kemudian dianalisis secara kualitatif dengan menguraikan secara deksriptif hasil data yang diperoleh terkait permasalahan dasar yang diteliti tentang faktor penyebab kekerasan, bentuk perlindungan hukum dan upaya penanggulangan kekerasan dalam rumah tangga.

\section{HASIL DAN PEMBAHASAN}

Dalam hasil penelitian yang diperoleh dari berbagai sumber, baik yang didapat di lokasi penelitian, maupun berdasarkan kajian terhadap peraturan perundang-undangan terkait perlindungan terhadap korban kekerasan, maka dapat di tarik sebuah kajian mendalam mengenai perlindungan hukum pidana bagi pekerja rumah tangga yang menjadi korban kekerasan oleh majikan. Pekerja rumah tangga dalam kehidupan domestik sesungguhnya memiliki peran sosial yang sangat penting. Pekerja rumah tangga tidak bisa disamakan dengan buruh yang merupakan kelas paling bawah dalam sistem ekonomi dan sosial di Indonesia. Jenis pekerjaan dari pekerja rumah tangga adalah bersifat khas (spesifik), sehingga meskipun secara yuridis memenuhi unsur-unsur tenaga kerja atau buruh pada umumnya sebagaimana diuraikan dalam ketentuan undang-undang ketenagakerjaan. Akan tetapi pekerjaan rumah tangga memiliki kekhasan tersendiri oleh karena selain berada dalam sektor domestik, pekerja rumah tangga juga menjadi bagian dari keluarga majikan.

Hasil penelitian yang dilakukan di kantor ILO (Internasional Labour Organization), cabang Sulsel, fakta menunjukan bahwa di Indonesia belum ada undang-undang yang khusus mengatur pekerja rumah tangga, tetapi beberapa undang-undang lain memberikan perlindungan seperti Undang-Undang Nomor 23 Tahun 2004 Tentang Penghapusan Kekerasan Dalam Rumah Tangga. Dari data yang diberikan Oleh Kepolisian Resort Kota Besar Makassar dalam hal unit Unit Perlindungan Perempuan dan Anak (PPA) menunjukan bahwa angka kasus kekerasan yang menimpa pekerja rumah tangga tidak terlalu banyak terjadi seperti yang terjadi Selama ini di daerah Jawa ataupun Sumatera.tetapi pihak kepolisian terus menggalang kerja sama dengan berbagai pihak untuk menekan angka kekerasan dalam rumah tangga, baik itu fisik, psikis, seksual maupun ekonomi, dengan berbagai indikator penanganan yang signifikan.

Adapun yang menjadi faktor penyebab dari pada kekerasan dalam rumah tangga yang menimpa pekerja rumah tangga adalah faktor interen dan faktor eksteren, kemudian bentuk perlindungan hukum yang diberikan kepada korban kejahatan kekerasan adalah perlindungan hukum preventif dan perlindungan hukum represif, serta 


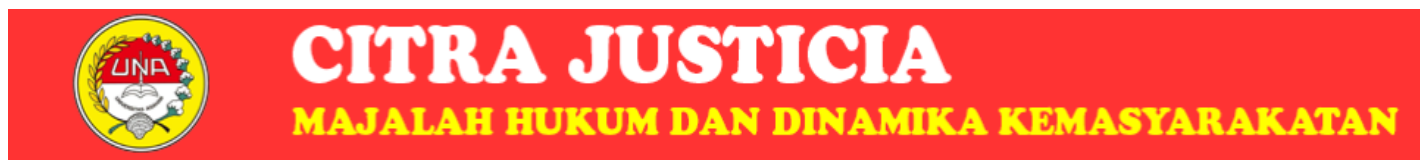

Volume 22 No. 1, FEBRUARI 2021 ISSN 2686-5750 (ONLINE)

ISSN 1411-0717 (CETAK)

upaya pencegahan yang dilakukan oleh berbagai pihak baik itu pemerintah, aparat penegak hukum maupun para pekerja sosial adalah dengan cara preemtif, preventif dan represif. Indikatorindikator diatas kemudian akan dibahas secara mendalam pada bagian pembahasan, sehingga dapat diketahui secara jelas mekanisme yang dilakukan oleh pihak-pihak terkait dalam melindungi korban kekerasan dalam rumah tangga.

Dalam penelitian ini hasil yang didapat adalah mengenai faktor penyebab kekerasan yaitu faktor interen (keadaan jiwa pelaku), dan faktor eksteren (keadaan diluar diri pelaku), dan juga bentuk perlindungan hukum pidana bagi pekerja adalah perlindungan preventif dan represif serta upaya penanggulangan kekerasan dalam rumah tangga yang dikaji dari hasil penelitian adalah upaya preemtif, prevetif dan upaya represif (Soeroso,2011).

Faktor internal adalah sebagai berikut: Kepribadian majikan yang otoriter, Perilaku seks menyimpang, Gangguan ledakan emosi tiba-tiba, Minimnya pengetahuan majikan akan keberlakukan Undang-undang Nomor 23 Tahun 2004 Tentang Penghapusan Kekerasan Dalam Rumah Tangga, Adanya relasi kuasa yg tdk setara antara majikan dng pekerja sehingga majikan mempunyai hak penuh terhadap diri pekerja yang akan berdampak pada tindakan kekerasan, Pekerja rumah tangga tidak menyelesaikan pekerjaan secara efektif, Pekerja kurang memahami penggunaan alat-alat rumah tangga yg berteknologi canggih, Pekerja kedapatan melakukan perbuatan pidana, seperti mencuri perhiasan milik majikan. Terhadap faktor interen ini yang ditinjau dari hasil penelitian mengemukakan bahwa keadaan emosional atau kondisi psikis dari majikan yang bersifat otoriter banyak terjadi di kalangan Tionghoa yang banyak menggunakan jasa pekerja rumah tangga. Lontaran kata ataupun kalimat yang sering dikelurkan kadang-kadang menyakiti hati, menyinggung perasaan, sehingga gerak langka pekerja rumah tangga kadang tidak bebas dan selalu di pasung.

Kemudian faktor eksteren sebagai penyebab kekerasan yang dilakukan terhadap diri pekerja rumah tangga oleh majikan adalah sebagai berikut: budaya patriarki yang membudaya dalam masyarakat Indonesia, Masalah ekonomi yang berkepanjangan yg melilit kebutuhan hidup rumah tangga majikan, Keterlibatan anak dalam pergaulan bebas, Kondisi lingkungan kerja majikan yang tidak begitu menyenangkanMasalah pekerjaan majikan yang bertumpuk pada tempat kerjannya sehingga menimbulkan kebuntuhan dalam berpikir yang akan berdampak pada tindakan sewenangwenang pada diri pekerja, Kondisi kehidupan rumah tangga yang diambang kehancuran, dan Belum adanya aturan hukum yg mengatur secara khusus tentang pekerja rumah tangga (saraswati, 2009).

Kemudian untuk permasalahan yang diteliti terkait kebijakan perlindungan hukum pidana yang diberikan bagi pekerja rumah tangga 


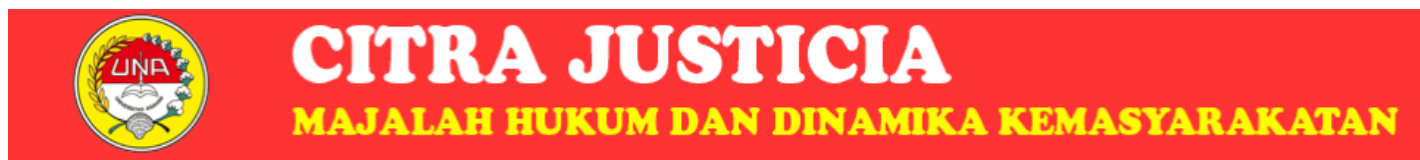

Volume 22 No. 1, FEBRUARI 2021 ISSN 2686-5750 (ONLINE)

ISSN 1411-0717 (CETAK)

sebagai korban kekerasan oleh majikan dapat dikaji berdasarkan bentuk perlindungan yang diberikan secara umum bagi korban kekerasan adalah sebagai berikut: Pemberian restitusi dan kompensasi (PP NO 44 Tahun 2008). kompensasi adalah: ganti kerugian yg diberikan oleh negara karena pelaku tidak mampu memberikan ganti rugi sepenuhnya yg seharusnya menjadi tanggungjawabnya, dan lebih bersifat keperdataan, karena permintaan timbul dari korban dan dibayar oleh negara atau merupakan bentuk pertanggungjawaban Negara (Mansur \& Gultom,2008). restitusi adalah: ganti kerugian yg diberikan oleh pelaku kepada korban, serta bersifat pidana, artinya bahwa, restitusi ini timbul dari Putusan Pengadilan dan dibayar oleh terpidana yg merupakan wujud pertanggungjawaban. Konseling, bentuk perlindungan hukum ini diberikan kepada korban kejahatan kekerasan sebagai akibat munculnya dampak negatif yg sifatnya psikis ( batin seseorang) dari suatu tindak pidana. (psikiater, pembimbing rohani). Pelayanan bantuan medis (visum et repertum) diberikan kepada korban kejahatan kekerasan yang menderita secara medis akibat suatu delik yg terjadi. Misalnya, luka berat dan korban meninggal dunia. (tenaga kesehatan).Bantuan hukum merupakan salah satu bentuk pendampingan terhadap korban salnya di kota Makassar, bantuan hukum banyak diberikan oleh lembaga sosial, misalnya lembaga bantuan hukum Asosiasi Perempuan Indonesia Untuk
Keadilan (LBH APIK), dan Forum Pemerhati Masalah Perempuan Sulawesi Selatan.

Menurut hemat penulis bahwa bentuk perlindunagn hukum dapat diberikan semaksimal mungkin kepada korban kejahatan, tetapi terkadang dalam lapangan praktik perlindungan hukum yang diberikan tidak sesuai harapan. Hal ini sangat bergantung kepada siapa pelaku dan siapa penegak hukum yang menangani perkara tersebut. Justru disini terjadi konspirasi atau permufakatan antara pelaku dengan penegak hukum untuk memanipulasi fakta yang terjadi, sehingga menimbulkan korban lebih banyak lagi. Hak-hak yuridis yang seharusnya diterima oleh korban terkadang diabaikan, seperti penerimaan ganti kerugian atas kehilangan harta benda, penggantian biaya pengobatan jika ada korban luka ringan maupun berat, dan lain-lain. Oleh karena itu untuk memaksimalkan proses pemberian perlindungan hukum kepada korban, maka sudah seharusnya dibentuk lembaga khusus untuk menangani masalah pemberian kompensasi dan restitusi, serta bentuk perlindungan hukum lainya, sehingga jelas nasib seseorang ketika menjadi korban dengan segala kerugian yang diderita.

Kemudian berdasarkan hasil yg penulis lakukan pada Lembaga Bantuan Hukum APIK, Makassar, dan Forum Pemerhati Masalah Perempuan Sulawesi Selatan, bahwa kebijakan perlindungan hukum yang diberikan kepada pekerja rumah tangga sebagai korban kekerasan oleh majikan, dapat ditempuh dengan mekanisme penal, 


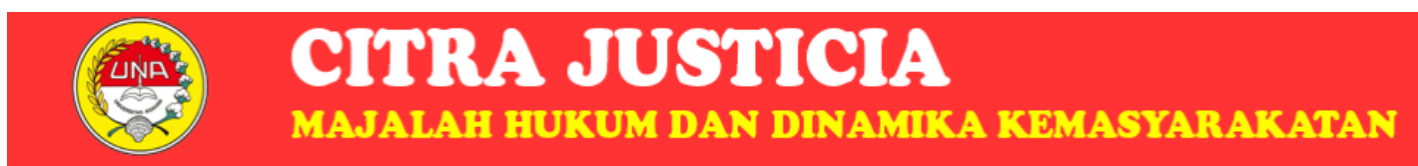

Volume 22 No. 1, FEBRUARI 2021 ISSN 2686-5750 (ONLINE)

ISSN 1411-0717 (CETAK)

dan non penal, adalah sebagai berikut: Melakukan kampanye tentang kerja layak bagi pekerja rumah tangga dan perlindungan hukumnya di indonesia berdasarkan keputusan Menteri Tenaga Kerja Nomor 313 tahun 2015 tentang Standar Kompetensi Kerja Nasional Indonesia (SKKNI), Melakukan pendampingan hukum terhadap korban pekerja rumah tangga dengan cara melaporkan majikan yg melakukan kekerasan kepada aparat Kepolisian (Unit PPA), Menghubungi Advokat untuk memberikan bantuan hukum terhadap korban KDRT, Melakukan jejaring kerjasama yang sinkron antara LBH APIK, Komnas Perempuan, pihak Kepolisian, Badan Pusat Pelayanan Terpadu Pemberdayaan Perempuan dan Anak Provinsi Sulsel dan Kota Makassar, dalam menangani setiap kasus kekerasan yg menimpa perempuan dan anak, khususnya PRT.

Dari pihak Kepolisian sendiri, mekanisme untuk memberikan perlindungan hukum adalah Dengan menindak tegas pelaku kekerasan dalam rumah tangga, (majikan) berdasarkan bukti yang cukup, Menyampaikan hak-hak yuridis yg seharusnya diterima oleh korban KDRT. (Pasal 10 UU PKDRT), Melakukan kerja sama dengan Kedokteran Forensik dalam hal meminta. visum et repertum, Memberikan perlindungan 1x 24 jam sejak diterima pengaduan oleh korban, dan memintah penetapan perintah perlindungan pada Pengadilan Negeri setempat.
Kemudian untuk permasalahan yang terkait dengan upaya penanggulangan kejahatan (criminal prevention), dapat dikaji secara umum yang digolongkan dengan tiga metode atau upaya adalah sebagai berikut: Upaya pre-emtif, upaya ini dilakukan dengan cara menanamkan nilai-nilai atau norma yg baik sehingga norma tersebut terinternalisasi dalam diri seseorang. Dalam metode ini faktor niat di hilangkan walaupun ada kesempatan melakukan kejahatan. Memberikan sosialisasi kepada masyarakat terkait keberlakukan UU PKDRT. Upaya preventif

merupakan tindak lanjut dari upaya pre-emtif yg masih dalam tataran pencegahan.dalam upaya ini yg ditekankan adalah menghilangkan kesempatan untuk dilakukan kejahatan.misalnya patroli yg dilakukan oleh kepolisian.Upaya represif, upaya ini dilakukan pada saat telah terjadi tindak pidana yang mekanismenya berupa proses penegakan hukum (law enforcement), dengan menindak tegas pelaku kejahatan berdasarkan bukti yang cukup dan meyakinkan bahwa terdakwa yg melakukan tindak pidana tersebut (Alam, 2010).

Kemudian berdasarkan hasil penelitian yg penulis lakukan pada Forum Pemerhati Masalah Perempuan yang sepak terjang tugasnya di bidang pemberdayaan pekerja rumah tangga, maka upaya penanggulangan kejahatan kekerasan dalam rumah tangga, adalah sebagai berikut: Mendirikan sekolah pekerja rumah tangga (SPRT), yg berlokasi di perumahan BTN Antang Jaya Blok A Nomor 7, Melakukan 


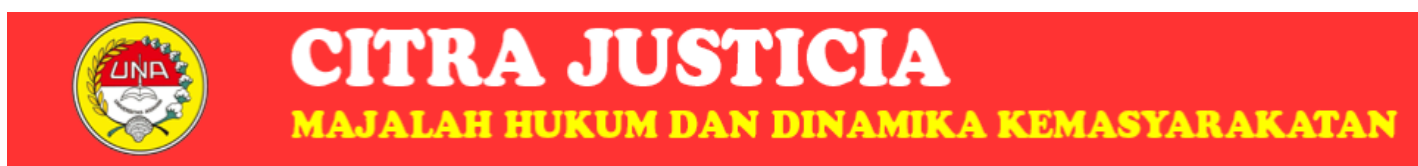

Volume 22 No. 1, FEBRUARI 2021 ISSN 2686-5750 (ONLINE)

ISSN 1411-0717 (CETAK)

sosialisasi terhadap hak-hak pekerja rumah tangga, dalam kapasitasnya jika menjadi korban kekerasan daam rumah tangga, sebagaimana telah diamanatkan oleh Undang-Undang Nomor 23 Tahun 2004 Tentang Penghapusan Kekerasan Dalam Rumah Tangga, Sosialisasi kerja layak bagi pekerja rumah tangga dalam konvensi ILO 189, Memberikan pelatihan terhadap penggunaan barang perlengkapan rumah tangga berteknologi tinggi dan dapat bekerja sama dengan Dinas Sosial Tenaga Kerja dan Transmigrasi (Blackett,1998).

Dari beberapa pokok permasalahan yang dikupas dalam penelitian ini dapat ditarik sebuah kesimpulan bahwa faktor penyebab kekerasan yang dilakukan oleh majikan terhadap diri pekerja rumah tangga adalah dipengaruhi oleh faktor interen dan eksteren, kemudian bentuk perlindungan hukum yang diberikan kepada pekerja rumah tangga jika menjadi korban kekerasan adalah dengan mengacu pada teori yang dicetuskan oleh Philipus Hadjon adalah perlindungan hukum preventif yang berati bahwa perlindungan ini diberikan secara tidak langsung oleh undang-undang yang mengakomodasi hak-hak yuridis dari pada korban kejahatan atau diberikan secara tidak langsung dan bersifat abstrak, kemudian bentuk perlindungan hukum represif yang berarti bahwa perlindungan hukum yang diberikan secara langsung atau nyata kepada korban kejahatan untuk melindungi diri pribadi dari gangguan ataupun ancaman kekerasan melalui proses penegakan hukum secara nyata, Serta upaya pencegahan kejahatan dapat ditempuh dengan mekanisme preemtif, preventif, dan represif yang Diberikan Oleh Pihak Pemerintah, Aparat Hukum Dan Pekerja Sosial Dengan Berbagai indikator kegiatan pelaksanaan yang sudah disebutkan diatas (Hadjon, 1987).

\section{KESIMPULAN}

Faktor penyebab kekerasan dalam rumah tangga yg dilakukan oleh majikan terhadap Pekerja rumah tangga antara lain dipengaruhi oleh faktor interen dan faktor eksteren, dimana faktor interen ini berkaitan dengan kondisi kepribadian majikan yg otoriter, perilaku seks menyimpang, dan tidak mandiri. Kemudian faktor eksteren berkaitan dengan kondisi tempat tinggal, kondisi tempat kerja,dan budaya patriarkhi yg membudaya. Bentuk perlindungan hukum pidana terhadap pekerja rumah tangga adalah bentuk perlindungan hukum preventif,dan perlindungan hukum represif. Upaya penanggulangan kekerasan dalam rumah tangga terhadap pekerja rumah tangga dapat dilakukan dengan tiga mekanisme yaitu, upaya pre-emif, preventif, dan represif. Ditujukan kepada pihak Kepolisian, Lembaga Bantuan Hukum Asosiasi Perempuan Iindonesia untuk Keadilan, Forum Pemerhati Masalah Perempuan, Pengadilan, serta Pemerintah untuk terus meningkatkan kerjasama dalam rangka menindak pelaku kekerasan serta mencegah segala bentuk kekerasan yg terjadi, Mendesak Dewan Perwakilan Rakyat Republik 


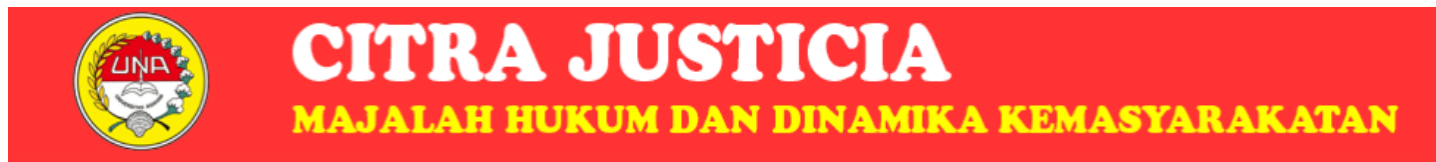

Volume 22 No. 1, FEBRUARI 2021 ISSN 2686-5750 (ONLINE)

ISSN 1411-0717 (CETAK)

Indonesia untuk segera memasukan rancangan Undang-Undang perlindungan pekerja rumah tangga kedalam Prolegnas untuk dibahas dan disahkan menjadi Undang-Undang, Menegaskan kepada para penyalur jasa pekerja rumah tangga untuk merancang aturan tertulis yang berupa

\section{DAFTAR PUSTAKA}

Buku

Alam A S .(2010). Pengantar kriminologi. Makassar:

Pustaka Refleksi Books.

Dellyana S .(1998).Wanita Dan Anak-Anak Di Mata Hukum. Yogyakarta: Liberty.

Hadjon M P. (1987). Perlindungan Hukum Bagi Rakyat Indonesia. Surabaya. Bina Ilmu.

Khaleed B .2015).Penyelesaian Hukum KDRT (Penghapusan Kekerasan Dalam Rumah Tangga Dan Upaya Pemulihanya). Yogyakarta: Pustaka Yustisia.

Mansur A D. \& Gultom E. (2008).Urgensi Perlindungan Korban Kejahatan (Antara Norma Dan Realita). Jakarta: Rajawali Pers.

Soeroso H M. (2011).Kekerasan Dalam Rumah Tangga Dalam Perspektif Yuridis- perjanjian kerja antara majikan dengan pekerja rumah tangga, Bagi Pemerintah Provinsi Sulawesi selatan dan Pemerintah Kota Makassar untuk segera membahas kebijakan baru terkait Peraturan Daerah (PERDA) tentang pekerja rumah tangga dengan segala aspek yang melatarbelakangi.

Viktimologis. Jakarta: Sinar Grafika.

Saraswati R .(2009).Perempuan Dan Penyelesaian Kekerasan Dalam Rumah Tangga. Bandung: Citra Aditya Bakti.

Syukur F .(2011).Mediasi Perkara KDRT (Kekerasan Dalam Rumah Tangga) Teori Dan Praktik Pengadilan Di Indonesia. Bandung: Cv.Mandar Maju.

Waluyo B .(2012).Viktimologi Perlindungan Saksi Dan Korban. Jakarta: Sinar Grafika.

\section{Website}

Blacket A.( 1998). making domestic work visible: the case fo spesifik regulation.Diakses pada 10 Mei 2016. Available from:

Http://Www.Ilo.Org/Publik 